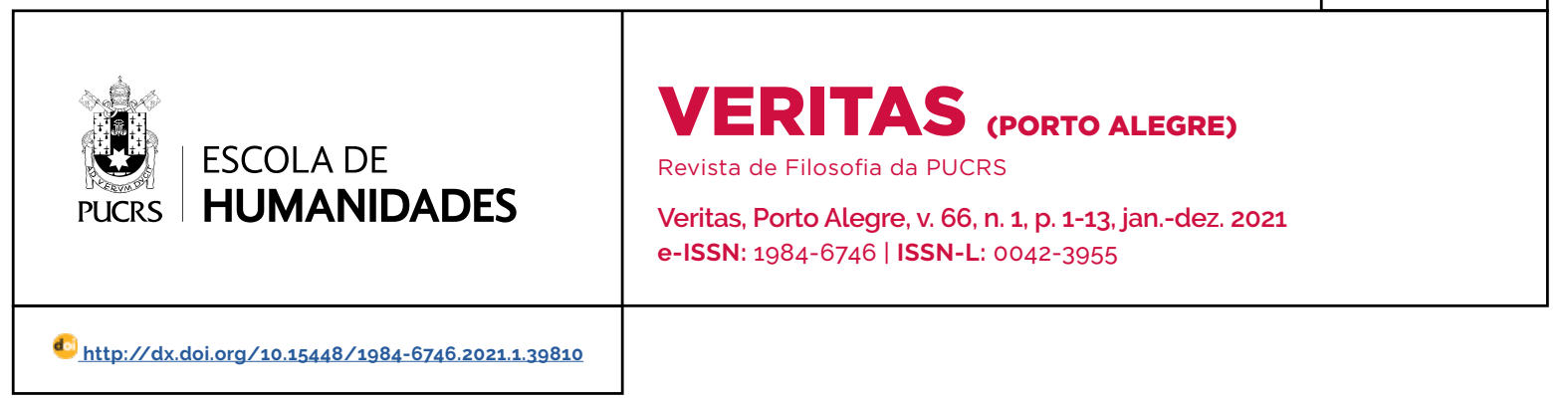

SEÇÃO: VARIA

\title{
Secularismo, religião e o problema da emancipação humana em Marx
}

\author{
Secularism, religion and the problem of human emancipation in Marx \\ Laicismo, religión y el problema de la emancipación humana en Marx
}

\section{Juliano Cordeiro da Costa Oliveira ${ }^{1}$ orcid.org/0000-0002-0844-6731 julianocordeiro81@gmail.com}

\section{Mayra Carneiro de Carvalho'} orcid.org/0000-0002-4691-8939 mayraccarvalho24@gmail.com

Recebido em: 29 dez. 2020. Aprovado em: 15 jun. 2021. Publicado em: 16 set. 2021.

\section{(c) (i)}

Artigo está licenciado sob forma de uma licença Creative Commons Atribuição 4.0 Internacional.
Resumo: O artigo objetiva investigar a relação entre secularismo e religião na sociedade burguesa à luz do problema da emancipação humana, a partir de escritos do jovem Marx, como, por exemplo, Sobre a Questão Judaica, Crítica da Filosofia do Direito de Hegel - Introdução, entre outros, que dizem respeito ao momento inicial de seu pensamento crítico; além de A Ideologia Alemã, obra posterior em que Marx retoma algumas das discussões iniciadas naquele periodo. A novidade trazida por Marx para o debate tradicional entre secularismo versus religião é que tudo isso só pode ser pensado a partir da emancipação humana, e não apenas da emancipação política. A sobrevivência da religião na modernidade não significa um desvio da secularização na história moderna, uma traição à Filosofia das Luzes ou mesmo um antagonismo em relação à emancipação política. Ao contrário, ela é consequência de uma secularização que não enfrentou as contradições de uma sociedade capitalista. Por um lado, Marx considerava a religião o "ópio do povo", e que toda critica teria como modelo a critica à religião. Por outro, entretanto, a religião não deixava de ser, ao mesmo tempo, um grito de revolta contra uma sociedade excludente e a miséria de um mundo. A hipótese. portanto, a ser investigada neste artigo é que a análise da religião, em Marx, não se reduz meramente a um anticlericalismo de sua época, uma vez que tem como horizonte a emancipação humana, e não apenas política. Não se trata, em Marx, de um simples combate entre as luzes e as trevas no plano das consciências, e, sim, acima de tudo, de uma crítica às contradições da sociedade burguesa. Marx não possui de forma sistematizada uma teoria crítica da religião. Deste modo, sistematizaremos determinadas discussões que Marx apresentou ao longo de seus escritos, objetivando investigar a problemática proposta neste artigo.

Palavras-chave: Marx. Secularismo. Religião. Emancipação humana.

Abstract: The present article aims to investigate the relationship between secularism and religion in the bourgeois society in the light of the human emancipation problem based on the writings of young Marx, such as, for example, On the Jewish Question, Critique of Hegel's Philosophy of Law - Introduction, among others, which concerned the initial moment of his critical thinking. In addition to The German Ideology, a later work in which Marx takes up some of the discussions initiated in that period. The newness brought by Marx to the traditional debate between secularism versus religion is that all such a matter might be only thought of, from human and not just from political emancipation. The survival of religion in modernity does not mean a deviation from secularization in modern history. a betrayal of the Philosophy of Light or even an antagonism towards political emancipation. It is the result of a secularization. Actually, that did not face the contradictions of a capitalist society. On the one hand, Marx considered religion to be the "opium of the people", and that all criticism would have as a model the religion criticism. On the other hand, however, religion would not stop being, at the same time, a guilty cry against an exclusionary society and the misery of a world. Therefore, the hypothesis to be investigated in this article is that the analysis of religion in Marx should not be merely reduced to an anticlericalism of his time. It has, as a horizon, human and not only political emancipation. As 
far as Marx is concerned, it is not just a matter of a simple struggle, between the Lights and the Dark on the level of consciousness, but, above all, a criticism of the bourgeois society contradictions. Marx does not have a systematic critical theory of religion. We may, this way, systematize certain discussions, which Marx presented throughout his writings aiming to investigate the problem proposed in this article.

Keywords: Marx. Secularism. Religion. Human emancipation.

Resumen: El artículo tiene como objetivo investigar la relación entre secularismo y religión en la sociedad burguesa a la luz del problema de la emancipación humana, basándose en escritos del joven Marx, como Sobre la cuestión judia, Crítica de la filosofia del derecho de Hegel - Introducción, otros, que se refieren al momento inicial de su pensamiento crítico; así como La ideología alemana, obra posterior en la que Marx retoma algunas de las discusiones iniciadas en ese periodo. La novedad aportada por Marx al debate tradicional entre laicismo versus religión es que todo esto solo se puede pensar desde la emancipación humana, y no solo desde la emancipación política. La supervivencia de la religión en la modernidad no significa una desviación de la secularización en la historia moderna, una traición a la Filosofía de la Ilustración o incluso un antagonismo hacia la emancipación política. Al contrario, es consecuencia de una secularización que no ha enfrentado las contradicciones de una sociedad capitalista. Por un lado, Marx consideraba a la religión como el "opio del pueblo", y que toda crítica se basaría en la crítica a la religión. Por otro lado, sin embargo, la religión fue al mismo tiempo un grito de rebelión contra una sociedad excluyente y la miseria de un mundo. La hipótesis, por tanto, a investigar en este artículo es que el análisis de la religión, en Marx, no se reduce meramente a un anticlericalismo de su tiempo, ya que su horizonte es la emancipación humana, y no solo política. En Marx, no se trata de una simple lucha entre Luces y Tinieblas a nivel de conciencias, sino, sobre todo, una crítica a las contradicciones de la sociedad burguesa. Marx no tiene una teoria crítica sistemática de la religión. De esta forma, sistematizaremos ciertas discusiones que Marx presentó a lo largo de sus escritos, con el objetivo de indagar en la problemática propuesta en este artículo. Palabras clave: Marx. Laicismo. Religión. Emancipación humana.

\section{Introdução}

A passagem da visão medieval para a moderna concepção do mundo político é conhecida como secularização (FLICKINGER, 2016). As transformações realizadas ao longo desse processo determinaram também a modelagem das constituições políticas que se estabeleceram nas sociedades ocidentais. De acordo com a visão secular de mundo, possibilitada historicamente pela modernidade ocidental, a fé passaria a ser relegada à esfera privada, instaurando, com isso, uma moral e uma razão imanentes. Outrora, segundo Charles Taylor, Deus estava ligado às únicas fontes morais que os homens podiam conceber. "Uma 'era de crença' é uma era em que todas as fontes morais dignas de confiança envolvem Deus" (TAYLOR, 2013, p. 402). Na pré-modernidade, a relação com Deus regia a relação entre os homens, isto é, a vida em sociedade.

No entanto, Marcel Gauchet (1985) assinala que assistimos, com a secularização, a um duplo processo relativo ao elemento religioso na contemporaneidade: de um lado, a saida da religião do espaço público; de outro, a individualização do crer. Com o advento da modernidade, a religião se retira do espaço público, permanecendo ativa na sociedade, porém restrita ao âmbito privado, individual. É somente no quadro desse processo de recolhimento das manifestações religiosas do espaço público que, para Gauchet, a emergência da democracia no Ocidente pode ser compreendida. Esse processo, de acordo com ele, seria irreversivel, uma vez que não haveria como voltar aos fundamentos incondicionais das religiões em sociedades democráticas, secularizadas e pluralistas: "Deus está separado. Ele não intervém nos assuntos políticos dos homens" (GAUCHET, 1998, p. 61). Não podemos falar, todavia, segundo Gauchet (1985, p. 292), no desaparecimento das religiões nas sociedades modernas, pois o processo descrito não significaria que "[...] o religioso deva parar de falar aos indivíduos". A religião não perdeu, mesmo com o processo de secularização, sua condição de reserva de sentido para muitos sujeitos.

Há, por outro lado, aqueles que defendem uma possivel volta da religiosidade na contemporaneidade, inclusive permeando o espaço público e o campo político-institucional, não estando mais a religião restrita ao âmbito privado, conforme se pode pensar a partir da perspectiva clássica da secularização, representada, aqui, por Gauchet. Nos paises do Leste Europeu, nos Estado Unidos e na América Latina, movimentos religiosos ganham força e reivindicam cada vez mais representatividade e poder na politica (THOMPSON, 2001). No 
presente artigo, faz-se importante indagar acerca de como Karl Marx insere-se nesse debate contemporâneo. Afinal, segundo Michael Löwy (1991), podemos encontrar, em Marx, conceitos, nuances e análises que podem nos ajudar a compreender a realidade nos dias de hoje.

A novidade trazida por Marx transcende o debate tradicional entre secularismo versus religião, apontando que tudo isso só pode ser pensado a partir de uma crítica à sociedade civil burguesa, às suas instituições, bem como ao modo capitalista de produção da vida material. A sobrevivência da religião na modernidade não significa um desvio da secularização na história moderna, uma traição à Filosofia das Luzes ou mesmo um antagonismo em relação à emancipação política. Ao contrário, ela é consequência de uma secularização que não enfrentou as contradições de uma sociedade capitalista.

Marx não formulou uma crítica sistematizada da religião. Por isso, apresentaremos, de modo ordenado, determinadas discussões presentes ao longo de seus escritos, principalmente os da década de 1840, em que o tema da religião é objeto de suas reflexões. Inicialmente, partiremos da crítica de Marx a Bruno Bauer em Sobre a Questão Judaica. Aqui, a análise de Marx tem como pano de fundo os limites da emancipação política defendida por Bauer como solução para a questão da concessão de direitos politicos aos judeus.

Para a compreensão da crítica da religião em Marx, mais decisiva ainda do que seu debate com Bauer, é, como aponta Karl Löwith (2014), a influência marcante de Ludwig Feuerbach sobre seu pensamento. Este realiza uma inflexão antropológica radical na filosofia, ao enfatizar que a teologia é, em realidade, uma antropologia, tal qual veremos no decorrer deste artigo. Feuerbach pretende resgatar o homem real, sensivel, haja vista que este não pode ser pensado fora da realidade material, e sim como ser natural - algo que influenciou profundamente Marx e sua análise da religião, mesmo que posteriormente ele venha a ser crítico do caráter contemplativo do materialismo de Feuerbach, conforme trataremos no último tópico deste artigo.

\section{Marx e a questão judaica}

Sobre a Questão Judaica, escrita em 1843. constitui uma resposta às concepções de Bruno Bauer, expressas em seu artigo "Die Judenfrage" [A questão judaica], publicada em 1842, nos Anais Alemães, bem como a seu artigo "Die Fähigkeit der heutigen Juden und Cristen, frei zu werden" [A capacidade dos atuais judeus e cristãos de se tornarem livres], publicado em um periódico suiço em 1843 (BENSAÏD, 2010). Em Sobre a Questão Judaica, Marx antecipou diversas questões debatidas ainda hoje, como o problema do reconhecimento das identidades religiosas e culturais, os limites da democracia formal, da emancipação política, bem como a relação entre secularismo e religião em uma sociedade de crises sociais e econômicas permanentes. Assim, podemos concordar com Jürgen Habermas quando afirma que

\begin{abstract}
persistimos até hoje no estado de consciência que os jovens hegelianos introduziram, quando se distanciaram de Hegel e da filosofia em geral. Desde então, estão em curso aqueles gestos triunfantes de suplantação reciproca, com os quais descuidamos do fato de que permanecemos contemporâneos dos jovens hegelianos (HABERMAS, 2002, p. 76).
\end{abstract}

As reflexões de Marx e de Bauer evoluíram de modo paralelo até o final de 1842, quando as divergências de concepções entre eles se tornaram irreconciliáveis, passando, então, a seguir caminhos opostos. Enquanto Marx partiu da crítica filosófica e a ampliou de modo a estabelecer as bases de uma crítica social e política, Bauer manteve-se restrito ao exercício filosófico como via de transformação profunda da realidade humana (PINTO, 2006). Ou seja, enquanto Marx partiu do idealismo, passando, por conseguinte, a orientar-se por uma perspectiva materialista, tendo como horizonte, não a compreensão contemplativa da realidade, mas sua transformação social, Bauer teria se limitado ao idealismo hegeliano, que concebe as transformações sociais como advindas de transformações no âmbito das ideias, o que constitui o inverso do materialismo.

É preciso lembrar que haveria, na leitura hegeliana da modernidade, tal qual argumenta 
Habermas (2002), a superioridade do mundo moderno e, ao mesmo tempo, sua tendência à crise, derivando em sua interpretação revolucionária e conservadora. A esquerda hegeliana, constituida pelos chamados jovens hegelianos, e a direita hegeliana, não fecharam os olhos para o potencial de conflito da sociedade burguesa e de suas contradições, mesmo que oferecessem leituras e propostas diversas para o potencial de crise da modernidade.

Nesse contexto, para Habermas (2002), a crítica dos hegelianos de esquerda intentava mobilizar o potencial da razão historicamente acumulado contra a racionalização unilateral do mundo burguês. A análise de Marx da questão judaica tem como pano de fundo o ponto onde a emancipação política, defendida por Bauer, mostra-se limitada por seu caráter inalienavelmente parcial, em contraposição à perspectiva da emancipação humana, enfatizada pelo próprio Marx. Segundo ele, o que Bauer sustenta é que a emancipação em relação à religião seria uma condição fundamental a ser colocada "tanto ao judeu que quer ser politicamente emancipado quanto ao Estado que deve emancipar e ser ele próprio emancipado" (MARX, 2010, p. 35). No caso de Bauer, a emancipação do Estado diz respeito à saída da religião do Estado, na direção de uma concepção de Estado laico.

Para Marx, as formulações de Bauer são unilaterais, pois submetem à crítica apenas o Estado religioso, cristão, dando à questão judaica um tratamento idealista e teológico. O que Bauer não percebeu é que a religião, seja judaica ou cristã, é uma expressão das relações sociais (OLIVEIRA, 2019). Marx não pretende simplesmente afirmar a existência e lançar críticas a um modo determinado de alienação - no caso, a alienação do discurso religioso -, enquanto manteria intacta a alienação da própria estrutura juridico-institucional do Estado moderno, que nos mesmos moldes da religião, aliena os sujeitos quanto à sua posição no modo de produção social do capitalismo. Em outras palavras, o Estado laico moderno, ou Estado político, como Marx (2010) o chama, constitui-se a partir do que podemos entender como a secularização de elementos próprios ao sistema religioso judaico-cristão.

A laicização do Estado não seria, portanto, muito mais do que a forma mais acabada de religião produzida, historicamente, pelo capitalismo. Com a incorporação de princípios religiosos à estrutura do Estado, em um modo secularizado, através do direito, tem-se como resultado não uma religião do Estado - não um Estado religioso, como seria o Estado cristão - mas o próprio Estado, a forma Estado, como religião, gerando o fetichismo do Estado (BENSAIID, 2010).

Deveriamos, segundo Marx, pensar em termos de uma emancipação humana, e não somente buscar a emancipação politica de alguns grupos da sociedade, incluindo-os apenas na igualdade juridica e formal do Estado burguês. Vale lembrar que a emancipação política por meio da concessão de direitos pelo Estado a esses grupos não é desconsiderada por Marx. Ao contrário, ele ressalta o ganho histórico das constituições burguesas, mesmo que limitadas.

\begin{abstract}
A emancipação politica de fato representa um grande progresso; não chega a ser a forma definitiva da emancipação humana em geral, mas constitui a forma definitiva da emancipação humana dentro da ordem mundial vigente até aqui. Que fique claro: estamos falando aqui de emancipação real, de emancipação prática (MARX, 2010, p. 41).
\end{abstract}

Para Bauer, segundo Marx (2010), o Estado deveria ser laico, emancipando-se da religião. Em Bauer, os judeus só seriam realmente emancipados caso se emancipassem do judaísmo para, então, entrarem no Estado político, alcançando uma emancipação política. Já o Estado político, constitucional, deveria renunciar, por sua vez, ao cristianismo. Para terem acesso à cidadania no Estado, os judeus deveriam, em Bauer, renunciar à sua religião, às suas concepções teológicas. A emancipação só seria possivel por meio de uma mudança total da essência religiosa dos indivíduos, entrando, eles, assim, no Estado laico e em suas constituições, usufruindo, por exemplo, dos 
direitos humanos ${ }^{2}$ um tema também presente em Sobre a Questão Judaica. Trata-se, portanto, em Bauer, fundamentalmente de uma emancipação política. Em torno de Bauer, como explica Althusser (2007), acentua-se a falta de inteligência das massas por não alcançarem a racionalidade em si do Estado, havendo um conflito, não entre a filosofia e o Estado, e sim entre a filosofia e as massas. Já Marx procura a irracionalidade do Estado e suas contradições (Althusser, 2007).

Daí, para Marx, o problema não seria apenas a retirada da religião do Estado, ou que os sujeitos deixem de ser religiosos para alcançar uma cidadania constitucional e os direitos humanos. A emancipação do judeu não equivale. em Marx, à sua emancipação do judaísmo, mas a emancipação da humanidade como um todo. De acordo com Marx, a questão de fundo não seria o judeu deixar de ser judeu, ou o religioso de ser religioso, tal qual um problema de consciência ou de uma identidade; deveríamos, em realidade, realizar uma crítica ao sistema econômico próprio à sociedade burguesa, ao qual ele se refere no texto supracitado, em termos de "economia nacional", dado o momento histórico do capitalismo na primeira metade do século XIX, quando se consolidavam os Estados-nação.

Em Marx, trata-se, sobretudo, de uma crítica à sociedade burguesa em seu caráter alienante. Em suas palavras, Bauer exige, por um lado, "que o judeu renuncie ao judaísmo, que o homem em geral renuncie à religião, para tornar-se emancipado como cidadão" (MARX, 2010, p. 36). Assim, pergunta Marx: "o ponto de vista da emancipação política tem o direito de exigir dos judeus a supressão do judaísmo e do homem de modo geral a supressão da religião?" (MARX, 2010, p. 37).

Marx opunha-se a uma mera crítica social da religião que se realizaria apenas na esfera do pensamento dos individuos, sem atingir as bases materiais que se expressam em uma dada compreensão da sociedade e em uma visão de mundo religiosa - conforme veremos mais à frente a propósito da crítica de Marx ao materialismo de Ludwig Feuerbach. Seria preciso, em uma palavra, uma crítica à sociedade burguesa, fundada no mercado, e de suas instituições próprias. "A emancipação do Estado em relação à religião não é a emancipação do homem real em relação à religião" (MARX, 2010, p. 46). Na emancipação política, defendida por Bauer, sairiamos apenas de um fetichismo da religião para um fetichismo do Estado. Assim, reduziríamos a emancipação humana ao seu caráter político e formal.

Em contraste com Bauer, Marx apoia a emancipação política dos judeus e dos religiosos sem exigir que renunciem à sua religião. Em outros termos, a emancipação dos religiosos não significa que estes deixem simplesmente suas identidades religiosas, como uma mudança de consciência rumo a uma cidadania abstrata, naquilo que Bauer denomina de emancipação política.

\begin{abstract}
Não estamos, portanto, dizendo aos judeus, como faz Bauer: vós não podeis vos tornar politicamente emancipados sem vos emancipar radicalmente do judaísmo. Estamos lhes dizendo, antes: pelo fato de poderdes vos emancipar politicamente sem vos desvincular completa e irrefutavelmente do judaísmo, a emancipação política não é por si mesma a emancipação humana. Se vós, judeus, querei vos emancipar politicamente sem vos emancipar em termos humanos, então a parcialidade e a contradição não se acham apenas em vós, mas também na essência e na categoria da emancipação politica (MARX, 2010, p. 46).
\end{abstract}

Para Marx, apenas a emancipação humana coloca verdadeiramente em questão a emancipação religiosa. Quando a alienação religiosa se enraíza na alienação política e social - bem como a reforça - não basta mais emancipar o Estado da

\footnotetext{
2 Marx, no escrito supracitado, aborda a questão dos direitos humanos, os quais estabeleceram-se primeiramente nos contextos das Revoluções Americanas e Francesa. Do caráter burguês dessas revoluções, Marx extrai o que ele denomina de emancipação política, categoria central em seu debate com Bauer tratado neste trabalho. A distinção entre direitos humanos e direitos políticos acompanha o processo de divisão entre a sociedade civil, composta pela vida individual, privada dos indivíduos e famílias, e a esfera política, pública, que diz respeito ao universal, composta pela associação dos cidadãos. Esse momento é concebido pela burguesia como o da realização da emancipação humana (PINTO, 2006). Marx, por sua vez, aponta a parcialidade da emancipação politica frente à amplitude da emancipação humana; como, também, faz uma crítica aos direitos humanos - os quais se contrapõem aos direitos dos cidadãos - como sendo "direitos do membro da sociedade burguesa, isto é, do homem egoísta, do homem separado do homem e da comunidade" (MARX, 2010, p. 48). Direitos esses que, em última instância, asseguram a propriedade privada e as condições da troca mercantil. Não nos deteremos mais na critica marxiana aos direitos humanos, pois excede os limites do presente artigo.
} 
religião através de uma reforma da consciência. "O Estado pode, portanto, já ter se emancipado da religião, mesmo que a maioria esmagadora continue religiosa. E a maioria esmagadora não deixa de ser religiosa pelo fato de ser religiosa em privado" (MARX, 2010, p. 39).

Marx, aqui, critica uma suposta universalidade atribuida à emancipação política. Anula-se, por um lado, a religião para, por outro, fundamentar o homem burguês e a propriedade privada, como se existisse de fato uma essência do homem burguês, privado das relações, que alcançaria supostamente uma emancipação e uma cidadania pela mudança apenas da consciência religiosa. "[...] o homem equivale a um ente genérico, ele é o membro imaginário de uma soberania fictícia, tendo sido privado de sua vida individual real e preenchido com uma universalidade irreal" (MARX, 2010, p. 41).

Assim, para Marx, a emancipação política defendida por Bauer seria a redução do homem a membro da sociedade burguesa. A crítica de Bauer resume-se a uma crítica teológica, ou seja, crítica às teologias cristãs e judaicas. Em Bauer, a liberdade completa do sujeito consistia em se chegar a uma superação da crítica à religião, através de uma "perda de si mesmo, somente superável por meio de uma total descristianização" (LÖWITH, 2014, p. 393). A libertação completa da religião é, em Bauer, mais que uma mera libertação: consiste em se chegar a ser autônomo e vazio, um ser livre de toda religião e seguro de si mesmo.

Porém, diz Marx, por mais que Bauer esteja se movendo criticamente, ainda se move no interior da teologia. Como explica Karl Löwith, a autoconsciência, para Bauer, constituia uma absolutização ideológica do princípio da sociedade civil burguesa. O que Marx contesta em Bauer são os "pressupostos sociais e políticos e as consequências da 'autoconsciência'" (LÖWITH, 2014, p. 394). Vale lembrar que não apenas por Marx, mas igualmente por Ruge e Stirner, Bauer era conhecido como um tipo de último teólogo, que "perseguiu a teologia com fanatismo teológico, e, justamente por isso, não se livrou da fé que ele combate" (LÖWITH, 2014, p. 392).
Marx (2010) observa que a questão judaica deve ser formulada de modo particular em cada Estado. E demonstra que, em sua época, tanto a Alemanha, que ainda constituía um Estado cristão por excelência, quanto a França, que já possuía o estatuto de um Estado constitucional, tratavam o problema da relação dos judeus com o Estado como uma questão de caráter de antagonismo religioso e teológico. Já os chamados estados livres norte-americanos teriam sido, segundo Marx (2010, p. 37), "o único lugar em que a questão judaica perdeu seu sentido teológico e se tornou uma questão realmente secular". E, com isso, afirma que

Só onde o Estado politico existe em sua for-
ma plenamente desenvolvida, a relação do
judeu, e de modo geral do homem religioso,
com o Estado politico, ou seja, a relação entre
a religião e o Estado, pode emergir em sua
peculiaridade, em sua pureza. A crítica a essa
relação deixa de ser uma critica teológica no
momento em que o Estado deixa de compor-
tar-se teologicamente para com a religião,
no momento em que ele se comporta como
Estado, isto é, politicamente, para com a reli-
gião. A critica transforma-se, então, em critica
ao Estado politico. Justamente no ponto em
que a questão deixa de ser teológica, a critica
de Bauer deixa de ser critica (MARX, 2010, p. 37).

Interessante notar que Marx, ao analisar a condição política dos Estado Unidos da época, cita Alexis de Tocqueville - ao lado de Gustave de Beaumont e Thomas Hamilton - em uma passagem pouco lembrada e comentada nos estudos de Sobre a Questão Judaica, mas de fundamental importância para nossa reflexão. Para Tocqueville, como sabemos, em A Democracia na América, a figura de Cristo, na religião, representa uma compreensão e um significado de que todos os membros da humanidade são semelhantes e iguais, pois são filhos de um Deus único, de um mesmo pai, uma ideia que marcou, sobretudo, a democracia americana e a sua fundação.

\footnotetext{
A ideia da unidade do gênero humano os leva sem cessar à ideia da unidade do Criador, ao passo que, ao contrário, homens muito separados uns dos outros e demasiados dessemelhantes chegam facilmente a criar tantas divindades quantos forem os povos, as castas, as classese as familias, e a traçar mil caminhos particulares para o céu (TOCQUEVILLE, 2014, p. 27).
} 
Na democracia americana, ser religioso e, ao mesmo tempo, membro de uma sociedade política, não constituía uma ruptura ou uma contradição interna ao processo de secularização, e sim uma continuidade, pois lá era possivel ser religioso no privado e no público, sem que fosse necessário se exigir que o religioso deixasse de ser religioso para ser membro de uma sociedade política, ao contrário da emancipação política defendida por Bauer. Por isso, como nos lembra Marx, remetendo-se a Tocqueville, era plenamente possivel ser religioso e ser membro de uma sociedade política, algo impensável para Bauer. Em Marx, a religião em si mesma não é um obstáculo à emancipação política (OLIVEIRA, 2019).

Segundo Marx, apesar de seu caráter secular, a América do Norte é, ao mesmo tempo, a terra da religiosidade.

A pergunta é: como se comporta a emancipação política plena para com a religião? Se até mesmo no país da emancipação política plena encontramos não só a existência da religião, mas a existência da mesma em seu frescor e sua força vitais, isso constitui a prova de que a presença da religião não contradiz a plenificação do Estado. Como, porém, a existência da religião é a existência de uma carência, a fonte dessa carência só pode ser procurada na essência do próprio Estado. Para nós, a religião não é mais a razão, mas apenas o fenômeno da limitação mundana. Em consequência, explicamos o envolvimento religioso dos cidadãos livres a partir do seu envolvimento secular. Não afirmamos que eles devem primeiro suprimir sua limitação religiosa para depois suprimir suas limitações seculares. Afirmamos, isto sim, que eles suprimem sua limitação religiosa no momento em que suprimem suas barreiras seculares, não transformamos as questões mundanas em questões teológicas. Transformamos as questões teológicas em questões mundanas (MARX, 2010, p. 38, grifo do autor).

Na emancipação política, defendida por Bauer, o Estado emancipa-se apenas da religião; entrementes, o Estado deveria, segundo Marx, se emancipar da religião do Estado. O Estado enquanto Estado pode não professar nenhuma religião, mas ainda sim professa a forma Estado. A cisão do homem em público e privado, em Bauer, não constitui um estágio, e sim, nas palavras de Marx, "a realização plena da emancipação política, a qual, portanto, não anula nem busca anular a religiosidade real do homem" (MARX, 2010, p. 42). A emancipação do Estado em relação à religião, como defende Bauer, não é ainda, segundo Marx, a emancipação do homem real em relação à religião. Para a crítica da religião em Marx, mais decisiva ainda do que seu debate com Bauer, é, como aponta Löwith, sua influência de Feuerbach: em Marx, "a crítica da religião de Feuerbach constitui um 'resultado inquestionável'" (LÖWITH, 2014, p. 395).

Como sabemos, Marx não possui propriamente uma teoria crítica da religião. Sua análise acerca do religioso nas sociedades foi profundamente influenciada por Feuerbach, que realiza uma inflexão antropológica radical na filosofia, ao enfatizar que a teologia é, em realidade, uma antropologia. Feuerbach pretende resgatar o homem real, sensivel, haja vista que este não pode ser pensado fora da realidade material, e sim como ser natural. Mesmo que Marx critique Feuerbach ao longo de seus escritos, sua análise foi profundamente influenciada pelo autor de $A$ Essência do Cristianismo, constituindo um momento fundamental para o aprofundamento da questão religiosa em Marx, bem como sua relação com o mundo secular, como veremos a seguir.

\section{A inflexão de Ludwig Feuerbach na antropologia filosófica: a teologia é uma antropologia}

"Todo o nosso propósito só pode consistir em colocar
as questões religiosas e politicas em sua forma hu-
mana autoconsciente, que é o que ocorre também na
crítica que Feuerbach faz à religião. Portanto, nosso
lema deverá ser: reforma da consciência, não pelo
dogma, mas pela análise da consciência mistica, sem
clareza sobre si mesma, quer se apresente em sua
forma religiosa ou na sua forma politica."

$(\operatorname{Karl} \operatorname{Mar})^{3}$

Para a compreensão da critica da religião empreendida por Marx nos anos 1840, é importante que se entenda, primeiro, a contribuição feita por Feuerbach ao debate da religião, tão caro à filoso- 
fia alemã da primeira metade do século XIX, que tanto influenciou Marx e Engels. É a religião, para Feuerbach (1988, p. 56), "a consciência primeira e indireta que o homem tem de si mesmo", a qual precederia a reflexão filosófica tanto na história da humanidade quanto na individual. Pois o homem primeiramente transpõe sua essência para fora de si e em seguida passa a conhecê-la e a contemplá-la, porém como a um objeto externo, distinto e independente de si. Sendo assim, todo progresso histórico na religião não deixaria de trazer consigo também um aprofundamento do conhecimento da humanidade sobre si mesma. Conhecimento este que somente poderia ser acessado, no entanto, tomando-se a religião como objeto de reflexão, como o faz a filosofia, ao demonstrar que os predicados atribuídos a Deus, seriam, na realidade, predicados humanos divinizados, e que a teologia é, de fato, uma antropologia.

Tudo o que existe já foi objeto da adoração religiosa; na essência e na consciência da religião nada mais está que o que já está em geral na essência e na consciência do homem sobre si mesmo e sobre o mundo. A religião não tem conteúdo próprio, especial. Mesmo os sentimentos de medo e terror tinham em Roma seu templo. Também os cristãos transformaram fenômenos psiquicos em essências, seus sentimentos em qualidades das coisas, as afeições que os dominavam em poderes que dominavam o mundo, em sintese, transformavam qualidades da sua própria essência, fossem elas conhecidas ou não, em seres autônomos (FEUERBACH, 1988, p. 64).

Feuerbach propõe uma concepção rigorosamente materialista do homem, definido como ser sensivel. Ele afasta-se, portanto, da tradição clássica do animal racional ou do kantiano, rejeitando igualmente o conceito hegeliano de Espirito. A religião é, em Feuerbach, a consciência da própria essência do homem: os atributos de Deus são os do homem. Sendo assim, Feuerbach devolve ao homem o status de sujeito desses predicados e, com isso, o status de ser.

Enquanto em Hegel há uma atribuição do serà ideia abstrata, há, também, uma abstração do ser concreto. "A ldeia é feita sujeito, na medida em que a ela é conferido o poder de engendrar, a partir de si mesma, suas determinações concretas, infinitas"
(ENDERLE, 2013, p. 25). Haveria, aí, portanto, uma inversão determinativa entre sujeito e predicado que equivale a uma "inversão ontológica entre a determinação real e a determinação ideal, o conteúdo concreto e a ideia abstrata ou, poder-se-ia dizer, o ser e o pensar" (ENDERLE, 2013, p. 25).

Feuerbach denuncia, por isso, "não um erro de método na especulação hegeliana, mas sim a falsidade da determinação ontológica em que o método está assentado" (ENDERLE, 2013, p. 26). A filosofia materialista de Feuerbach é a dissolução da teologia em antropologia. Compreender Deus é, primeiramente, compreender o homem, ser este pertencente à natureza. Como exemplifica Lima Vaz (2006), Feuerbach realiza uma inflexão materialista da lógica e da metafísica hegelianas, cujas consequências atingem, em primeiro lugar, a Filosofia do Espírito Absoluto (religião e filosofia) para incidir, em seguida, sobre a concepção de homem. A filosofia de Feuerbach é, segundo Vaz (2006), um antropocentrismo radical, diferente, entretanto, da representação central do homem na estrutura do cosmos antigo.

De um lado, essa dissolução tem como resultado uma antropologia materialista: o homem como ser sensivel define-se por suas carências e, consequentemente, por sua relação com o mundo. Essa relação permite caracterizar o homem como ser genérico, ou seja, aberto aos outros homens e à totalidade do gênero humano que, na verdade, "é o sujeito real dos atributos que o homem individual projeta em Deus" (VAZ, 2006, p. 117).

Na perspectiva de Feuerbach, a religião é a expressividade da essência humana, pois o verdadeiro significado da teologia é a antropologia. O filho de Deus é um filho real, advindo da sensibilidade humana. Feuerbach enfatiza que os mistérios da teologia constituem os da própria sensibilidade humana. Para ele, não há o mistério de Deus, e sim o dos homens: "[...] ao reduzir a teologia à antropologia na verdade elevo a antropologia para a teologia assim como o cristianismo que ao reduzir Deus ao homem, fez do homem um Deus" (FEUERBACH, 1988, p. 31).

Dessa forma, a essência de Deus é o produto da efetividade humana. Erudição e filosofia são 
apenas, diz Feuerbach, meios para mostrar o tesouro escondido no homem. A religião retira seus significados de dentro do próprio homem, entretanto, trabalha-os como se em Deus não habitasse a sensibilidade humana. A consciência de Deus é a consciência que o homem tem de si mesmo.

A teologia separou o homem de Deus como se este fosse um ser independente do homem. Pelo Deus, afirma Feuerbach, conhece-se o homem, e, pelo homem, conhece-se Deus, uma vez que ambos são a mesma coisa. Deus é a intimidade humana revelada, o pronunciamento do Eu do homem. Em uma palavra, a religião é a revelação do homem oculto, a confissão dos seus mais íntimos pensamentos, a manifestação pública dos seus segredos. Quanto mais pobre e vazia for a vida do homem, mais rico e concreto será o seu Deus. $O$ esvaziamento do mundo real e o enriquecimento da divindade constituem-se em um único ato. "Deus é o que o homem quer ser - a sua própria essência, a sua própria meta, representada como ser real" (FEUERBACH, 2002, p. 76).

Portanto, o "desesperado sentimento do vazio e da solidão necessita de um Deus no qual exista sociedade, uma união de seres que se amam intimamente" (FEUERBACH, 1988, p. 116). A essência da teologia é, por isso, em Feuerbach, a do homem projetada para fora dele. Características como amor e bondade são, em primeiro lugar, predicados que definem o homem. Posteriormente, tais predicados são postos em Deus. Para Feuerbach, o homem, portanto, é o início, o meio e o fim da religião, algo que influenciou diretamente Marx e sua reflexão sobre a religião.

No entanto, apesar da fundamental influência de Feuerbach em Marx, a concepção feuerbachana do mundo sensivel limita-se, por um lado, à mera contemplação deste último e, por outro, à mera sensação. Conforme Marx e Engels (2007, p. 30), em sua crítica a Feuerbach presente em A Ideologia Alemã, este versa sobre "o homem", e não sobre os "homens históricos reais". Em outras palavras, Feuerbach não veria que o mundo sensivel que o rodeia não é algo dado imediatamente e imutável, que permaneceria sempre idêntico a si mesmo, mas produto do desenvolvimento das forças produtivas que baseia o estado de coisas e as concepções da sociedade em cada momento histórico. Como explicita Löwith (2014), enquanto Feuerbach almejava descobrir o chamado núcleo terreno da religião, Marx dá um passo adiante e desenvolve uma análise histórica das relações terrenas e contradições que possibilitam e tornam necessária a religião, para além da mera sensibilidade humana, condicionada, sobretudo, às relações econômicas, históricas e sociais, como veremos a seguir.

\section{A crítica de Marx a Feuerbach}

Para Marx e Engels (2007a), são também determinadas as relações sociais e politicas que os homens estabelecem entre si a partir do modo como produzem sua vida material. Assim como a produção de ideias, de representações, da consciência, o representar e o pensar, o intercâmbio espiritual dos homens igualmente derivaria do caráter de sua atividade material. "O mesmo vale para a produção espiritual, tal como ela se apresenta na linguagem da política, das leis, da moral, da religião, da metafísica etc. de um povo" (MARX; ENGELS, 2007a, p. 93-94). Nessa perspectiva, Marx e Engels, seguindo Feuerbach, denunciam a inversão característica da filosofia idealista de tradição hegeliana, mesmo em sua versão crítica à Hegel, representada pelos jovens hegelianos.

Essa inversão diz respeito a tomar a natureza e o mundo sensivel, material, como derivados das ideias ou conceitos, e das consciências correspondentes a estes, cuja representação maior no sistema hegeliano se dá pela noção de espirito absoluto, conforme mencionado acima, mas que toma formas parciais e distintas no pensamento de cada filósofo do hegelianismo de esquerda em particular. Essa crítica materialista foi inaugurada por Feuerbach, à luz da inflexão antropológica radical que realizou, ao demonstrar que os elementos da teologia encontram sua base na materialidade da existência humana, conforme exposto anteriormente. Marx e Engels, então, baseados em Feuerbach, denunciam o caráter ideológico dessa inversão que toma como independentes e autônomas, frente aos homens, formas derivadas de e condicionadas ao próprio 
modo como sua vida material é produzida em condições históricas determinadas.

A moral, a religião, a metafisica e qualquer outra ideologia, bem como as formas de consciência a elas correspondentes, são privadas, aqui, da aparência de autonomia que até então possuiam. Não têm história, nem desenvolvimento; mas os homens, ao desenvolverem sua produção e seu intercâmbio materiais, transformam também, com esta sua realidade, seu pensar e os produtos do seu pensar. Não é a consciência que determina a vida, mas a vida que determina a consciência (MARX; ENGELS, 2007a, p. 94).

Na contramão da filosofia alemã de sua época - à qual atribuirão a expressão "ideologia alemã", homônima ao título do manuscrito aqui citado -, Marx e Engels, partirão dos homens em sua existência material e determinada para chegar às abstrações que desta derivam, enquanto expressões contingentes suas que terminam por figurar como "sublimações necessárias" (MARX; ENGELS, 2007a, p. 94) desta. Eles expõem os pressupostos materiais que condicionam as ideias, representações, a política, a moral, a religião etc. de uma dada época. E nesse aspecto vão além de Feuerbach na crítica materialista.

Segundo Marx e Engels (2007a), Feuerbach tem, em relação aos materialistas "puros", a grande vantagem de compreender que o homem é também "objeto sensível". Contudo, Feuerbach apreende o homem unicamente como "objeto sensivel", e não como "atividade sensivel", pois detém-se ele ainda no plano da teoria, não concebendo os homens em suas determinações sociais. Feuerbach não chega aos homens ativos, realmente existentes. Ele permaneceria na abstração ao tratar apenas do "homem" como ser abstrato, genérico, não indo além do reconhecimento do plano sentimental do homem, não o reconhecendo em suas relações sociais concretas mediadas pela atividade produtiva. O que se dá no plano subjetivo, na consciência, para usar um termo marxiano, já é, para Marx, desde sempre, um produto social, algo que advém das características e condições com que os homens produzem sua vida material em um contexto histórico.

Os homens, ao desenvolverem sua produção e seu intercâmbio material, desenvolvem e transformam, igualmente, seu pensar e sua subjetividade. Segundo Marx, o principal problema de todo o materialismo existente, incluindo o de Feuerbach, é que seu objeto - a realidade, o sensível - só é apreendido sob a forma do objeto ou da contemplação. "Ele (Feuerbach) não entende, por isso, o significado da atividade 'revolucionária', 'prático-crítica'" (MARX, 2007b, p. 533).

Na interpretação de Marx, Feuerbach não estende sua concepção do sensivel à atividade prática. Ele dissolve a essência religiosa na essência humana, assimilando a teologia à antropologia, conforme demonstrado acima. Porém, a essência humana seria, segundo Marx, não uma abstração intrínseca ao indivíduo isolado, como pensa Feuerbach, e sim o conjunto das relações sociais. Ou seja, Feuerbach pressupõe um individuo abstrato, isolado, e uma essência humana abstraída da concretude da existência dos homens em uma dada sociedade. Não percebe que o próprio sentimento religioso é um produto social, derivado do modo como é produzida a vida material em uma sociedade; bem como não considera que o indivíduo abstrato é constituido socialmente. De acordo com Marx, "toda vida social é essencialmente prática. Todos os mistérios que conduzem a teoria ao misticismo encontram sua solução racional na prática humana e na compreensão dessa prática" (MARX, 2007b, p. 534. grifo do autor). Daí sua clássica sentença: "os filósofos interpretam o mundo de diferentes maneiras; o que importa é transformá-lo" (MARX, 2007b, p. 534, grifo do autor).

Por um lado, Marx apreende de Feuerbach sua assertiva crítica de que a teologia é, em realidade, uma antropologia; de outro, todavia, Marx realiza uma crítica a Feuerbach no que este pensa uma essência humana intrínseca, abstraída das relações sociais engendradas pelo modo de produção da vida material. A religião em sua época é, então, para Marx, uma certa expressão da realidade social, onde figuram tanto o sentimento da carência vivida quanto de revolta contra essa condição, como uma espécie de resposta à sociedade mercantil burguesa, sendo fruto das relações sociais estabelecidas nessa sociedade. Assim, "a miséria 
religiosa constitui ao mesmo tempo a expressão da miséria real e o protesto contra a miséria real" (MARX, 2013, p. 151, grifo do autor).

Na Crítica da Filosofia do Direito de Hegel - Introdução, Marx (2013, p. 151.) afirma que "a crítica da religião é o pressuposto de toda crítica". Portanto, "a crítica da religião é, pois, em germe, a crítica do vale de lágrimas, cuja auréola é a religião" (MARX, 2013, p.152, grifo do autor). Para ele, "A crítica do céu transforma-se, assim, na crítica da terra, a crítica da religião, na crítica do direito, a critica da teologia, na crítica da política" (MARX, 2013, p. 152, grifo do autor). A religião figura, por um lado, segundo Marx, como o "ópio do povo" (MARX, 2013, p. 151, grifo do autor). No entanto, ela é, ao mesmo tempo, "o suspiro da criatura oprimida, o ânimo de um mundo sem coração, assim como o espírito de estados de coisas embrutecidos" (MARX, 2013, p. 151).

Ao negar este mundo para afirmar um outro, no além, a religião reflete as contradições da própria sociedade. A crítica de Marx da religião consiste não apenas na sua humanização, como em Feuerbach - no desvelamento de sua essência enquanto essência humana a partir da revelação do caráter humano de seus predicados - ou em sua mera rejeição acrítica, como propõe Bauer, mas na exigência critica de abolir romper com as condições que pressupõem necessariamente a religião, enquanto uma promessa de "felicidade ilusória do povo" (MARX, 2013, p. 151, grifo do autor), a encobrir a fonte real das carências que geram a infelicidade deste. Por conseguinte, "a exigência de que abandonem as ilusões acerca de uma condição é a exigência de que abandonem uma condição que necessita de ilusões" (MARX, 2013, p. 151-152).

Em seus escritos publicados conjuntamente nos Anais Franco-Alemães, em 1844, aqui mencionados acima - a saber, Sobre a Questão Judaica e Crítica à filosofia do Direito de Hegel - Introdução - Marx passa a situar a questão no âmbito da própria sociedade civil burguesa, em suas contradições imanentes, das quais tanto a religião quanto o Estado e o Direito são expressões igualmente contraditórias.

\begin{abstract}
Minha investigação desembocou no seguinte resultado: relações juridicas, tais como formas de Estado, não podem ser compreendidas nem a partir de si mesmas, nem a partir do assim chamado desenvolvimento geral do espirito humano, mas, pelo contrário, elas se enraízam nas relações materiais de vida, cuja totalidade, foi resumida por Hegel sob o nome de "sociedade civil" (bürgerliche Gesellschaft), seguindo os ingleses e franceses do século XVIII; mas que a anatomia da sociedade burguesa (bürgerliche Gesellschaft) deve ser procurada na economia política (MARX, 1978, p. 129).
\end{abstract}

Marx parte da separação contraditória moderna entre Estado e sociedade, chegando aos fundamentos contraditórios dessa própria sociedade, assentada como está na propriedade privada. Daí, como vimos ao longo deste artigo, a crítica de Marx ao caráter parcial e limitado da emancipação politica defendida por Bauer. Trata-se, em Marx, acima de tudo, da emancipação humana, à luz da crítica da economia política e da lógica do capital que ele aprofundará ao longo de sua vida.

\section{Considerações finais}

O presente artigo propôs a tratar dos limites da emancipação política ou da participação de determinados grupos, até então excluidos, no âmbito do Estado político através da concessão de direitos politicos. Partimos do debate entre Bauer e Marx, expresso na obra Sobre a Questão Judaica deste último, onde se dá a discussão sobre a emancipação política dos judeus. Bauer concebe a solução da questão como sendo o abandono da religião por parte dos judeus em troca de sua participação no Estado político, bem como o abandono deste de qualquer religião, tornando-se laico. Seria esse processo proposto por Bauer algo semelhante ao que seria o processo de secularização atribuido à modernidade, no qual a religião é retirada da esfera pública, do âmbito político, e passaria a ser exercida apenas na esfera privada.

Marx, por sua vez, apontará justamente os limites, o caráter parcial da emancipação política e, portanto, da secularização, no que diz respeito à emancipação do homem, quando não se enfrenta as contradições que engendram a alienação do homem, que tem na alienação religiosa seu modelo - ou seja, as contradições da sociedade 
civil burguesa, o qual diz respeito à propriedade privada dos meios produtivos por uma classe, a classe burguesa - e que não é passivel de resolução na esfera estatal como teria afirmado Hegel, na interpretação de Marx.

Nessa perspectiva, é possivel inferir, tal qual sugere Ruy Fausto (2009) que, em Marx, frente à questão da religião, impõe-se uma posição que não corresponderia nem a de um Iluminismo acrítico - no sentido de um anticlericalismo meramente burguês, que se esgota na defesa da laicidade das instituições e da esfera política da sociedade, a começar pelo Estado -, nem a de um anti-iluminismo. Em realidade, "seria crítica do lluminismo (ou aufklärer "suprimida", no sentido de Hegel), critica da Aufklärung, ou Aufklärung crítica" (FAUSTO, 2009, p. 32). O suprassumir hegeliano, referência fundamental para Marx, apresenta, em seu bojo, um duplo significado: ele é, de uma só vez, um negar e um conservar, assim como um conservar e um negar. Em outros termos, não se trata, em Marx, à luz da dialética hegeliana, nem de um ingênuo lluminismo burguês e acrítico das relações e condições sociais, como o de Bauer, nem de um anti-iluminismo; e sim de um iluminismo crítico e reflexivo que denuncia as contradições da sociabilidade burguesa, para ultrapassá-la, haja vista a defesa de Marx, não somente de uma emancipação política, e sim, sobretudo, de uma emancipação humana.

\section{Referências}

ALTHUSSER, L. Politica e História: de Maquiavel a Marx. São Paulo: Martins Fontes, 2007.

BENSAÏD, D. Apresentação. In: MARX, K. Sobre a Questão Judaica. São Paulo: Boitempo, 2010. p. 9-29.

ENDERLE, R. Apresentação. In: MARX, K. Critica da Filosofia do Direito de Hegel. São Paulo: Boitempo, 2013. p. 17-32.

FAUSTO, R. Outro Dia: intervenções, entrevistas, outros tempos. São Paulo: Perspectiva, 2009.

FEUERBACH, L. A Essência do Cristianismo. Campinas: Papirus, 1988.

FEUERBACH, L. Principios da Filosofia do Futuro e Outros Escritos. Lisboa: Edições 70, 2002.

FLICKINGER, H. A Filosofia Politica na Sombra da Secularização. São Leopoldo: UNISINOS, 2016.
GAUCHET, M. Le dédenchantement du monde: une historie politique de la religion. Paris: Gallimard, 1985.

GAUCHET, M. La religion dans la démocratie: parcours de la laïcité. Paris: Gallimard, 1998.

HABERMAS, J. O Discurso Filosófico da Modernidade. São Paulo: Martins Fontes, 2002.

LÖWITH, K. De Hegel a Nietzsche: a ruptura revolucionária no pensamento do século XIX: Marx e Kierkegaard. São Paulo: Unesp, 2014

LÖWY, M. Marxismo e Teologia da Libertação. São Paulo: Cortez Editora, 1991.

MARX, K. Para a crítica da Economia Política. In: MARX, K. Manuscritos econômico-filosóficos e outros textos escolhidos (Os Pensadores). São Paulo: Abril Cultural, 1978. p. 107-131

MARX, K.; ENGELS, F. A Ideologia Alemã. São Paulo: Boitempo, 2007a.

MARX, K. Ad Feuerbach. In: MARX, K.; ENGELS, F. A ldeologia Alemã. São Paulo: Boitempo, 2007b. p. 533-535.

MARX, K. Sobre a Questão Judaica. São Paulo: Boitempo, 2010.

MARX, K. Crítica da Filosofia do Direito de Hegel - Introdução. In: MARX, K. Crítica da Filosofia do Direito de Hegel. São Paulo: Boitempo, 2013. p. 151-163.

OLIVEIRA, R. Da crítica da religião à crítica da política em Marx: sobre a necessidade de pensar a emancipação para além da política democrático-burguesa. Revista Helius, Sobral, v. 2, n. 1, p. 65-87, jan./jun. 2019.

PINTO, M. M. "A Questão Judaica" e a crítica de Marx à ideologia dos direitos do homem e do cidadão. Controvérsia, São Leopoldo, v. 2, n. 1, p. 10-16, jan./jun. 2006. Disponivel em: http://revista.unisinos.br/index. $\mathrm{php/controversia/article/view/7087.} \mathrm{Acesso} \mathrm{em:} 20$ dez. 2020.

TAYLOR, C. As Fontes do Self: a constituição da identidade moderna. São Paulo: Edições Loyola, 2013.

TOCQUEVILLE, A. A Democracia na América (livro II): sentimentos e opiniões: de uma profusão de sentimentos e opiniões que o estado social democrático fez nascer entre os americanos. São Paulo: Martins Fontes, 2014.

THOMPSON, J. A midia e a modernidade: uma teoria social da mídia. 3. ed. Petrópolis: Vozes, 2001.

VAZ, L. Antropologia Filosófica I. São Paulo: Edições Loyola, 2006.

\section{Juliano Cordeiro da Costa Oliveira}

Doutor em Filosofia pela Universidade Federal do Ceará (UFC), em Fortaleza, CE, Brasil, com doutorado sanduiche pela Ludwig Maximilian-Universität (LMU), em Munique, Alemanha. Pós-doutorando em Filosofia pela Universidade Federal do Piaui (UFPI), em Teresina, PI, Brasil. 


\section{Mayra Carneiro de Carvalho}

Mestre pelo Programa de Pós-Graduação em Psicanálise da Universidade do Estado do Rio de Janeiro (UERJ), no Rio de Janeiro, RJ, Brasil. Graduada em Psicologia pela Universidade de Fortaleza (UNIFOR), em Fortaleza, CE, Brasil.

\section{Endereço para correspondência}

Juliano Cordeiro da Costa Oliveira

Universidade Federal do Piauí

Campus Min. Petrônio Portela, s/n

Ininga, 64049-550

Teresina, PI, Brasil

Os textos deste artigo foram revisados pela Poá Comunicação e submetidos para validação do(s) autor(es) antes da publicação. 